\title{
EKG-gyöngyszem: Pseudoinfarctusos Q-hullámok és alacsony kilengések
}

\author{
Tomcsányi János dr. \\ Betegápoló Irgalmasrend Budai Irgalmasrendi Kórháza, Kardiológiai Osztály, Budapest
}

\begin{abstract}
Egy „terápiarefrakter” szívelégtelen beteg EKG-ja kerül bemutatásra, ahol az EKG-n a szívelégtelenség kiváltó tényezőjének nagyon specifikus EKG-jelei láthatók.

Orv Hetil. 2018; 159(8): 327-329.
\end{abstract}

Kulcsszavak: EKG, low voltage, amyloidosis, Q-hullám, szívelégtelenség

\section{ECG pearls: Pseudoinfarct $Q$ waves and low voltage}

Therapy refracter heart failure is presented. The admission ECG shows low voltage and pseudoinfarct Q waves highly diagnostic for the etiology of heart failure.

Keywords: low voltage, heart failure, pseudoinfarct Q wave

Tomcsányi J. [ECG pearls: Pseudoinfarct Q waves and low voltage.] Orv Hetil. 2018; 159(8): 327-329.

(Beérkezett: 2017. november 20.; elfogadva: 2017. november 28.)

\section{Rövidítések}

AL-amyloidosis = könnyúlánc-amyloidosis; DCM = dilatativ cardiomyopathia; $\mathrm{EKG}=$ elektrokardiográfia; $\mathrm{HCM}=$ hypertrophiás cardiomyopathia; NT-proBNP $=\mathrm{N}$-terminális agyi natriureticus peptid; PTX = légmell; WPW = Wolf-ParkinsonWhite által leírt preexcitációs szindróma

Az 55 éves nőbetegnél két évvel ezelőtt hólyagkőmütét kapcsán készült EKG, ahol szóltak neki, hogy „ronda az EKG”-ja. Mivel semmilyen panasza nem volt, nem történt kivizsgálás. Szívelégtelenségre utaló tünetei két hónapja kezdődtek, amelyekkel több egészségügyi ellátóhelyen is járt.

A beteg felvételét az osztályunkra terápiarefrakter diasztolés szívelégtelenség miatt kérik. A felvételi EKG-t az 1. ábra mutatja.

A szívultrahang-vizsgálat koncentrikus balkamrahypertrophiát mutatott egy nem hypertoniás betegnél. A bal kamrai ejekciós frakciója $55 \%$ volt, normál tágasságú bal kamra mellett a bal pitvar mérsékelten dilatált (45 mm), a mitralis beáramlási görbe restriktív volt, de pericardialis fluidum nem volt. Az NT-proBNP pedig 3000 ng/l feletti értékével igazolta a szívelégtelenséget. A klinikai kép alapján amyloidosisra gondolva a hasfali subcutisból vettünk biopsziát, ami igazolta a diagnózist. Ezzel párhuzamosan a szérumelektroforézis monoklonális gammopathiát mutatott, míg a vizeletben proteinuria volt (Bence-Jones-protein). A beteget Hematológiai Osztályra helyeztük át, ahol az elvégzett csontvelö-biopszia plasmocytomát mutatott. Az AL-amyloidosisos beteg a Hematológiai Osztályon sajnos néhány napon belül elhalálozott. A rapid lefolyás nem engedte meg az érdemi kezelést. A korai EKG - amelyet később sikerült megszerezni - már korán jelezte, hogy a panaszmentesség ellenére valami baj van a szívvel (2. ábra).

\section{EKG-analízis}

$\mathrm{Az}$ 1. ábrán a standard elvezetésekben olyan kicsik a QRS-kilengések, hogy zavarba ejtő, hogy melyik a Phullám, és melyik a QRS. De nemcsak $5 \mathrm{~mm}$ alattiak a kilengések, hanem az I-II-aVL-elvezetésekben QS látha- 

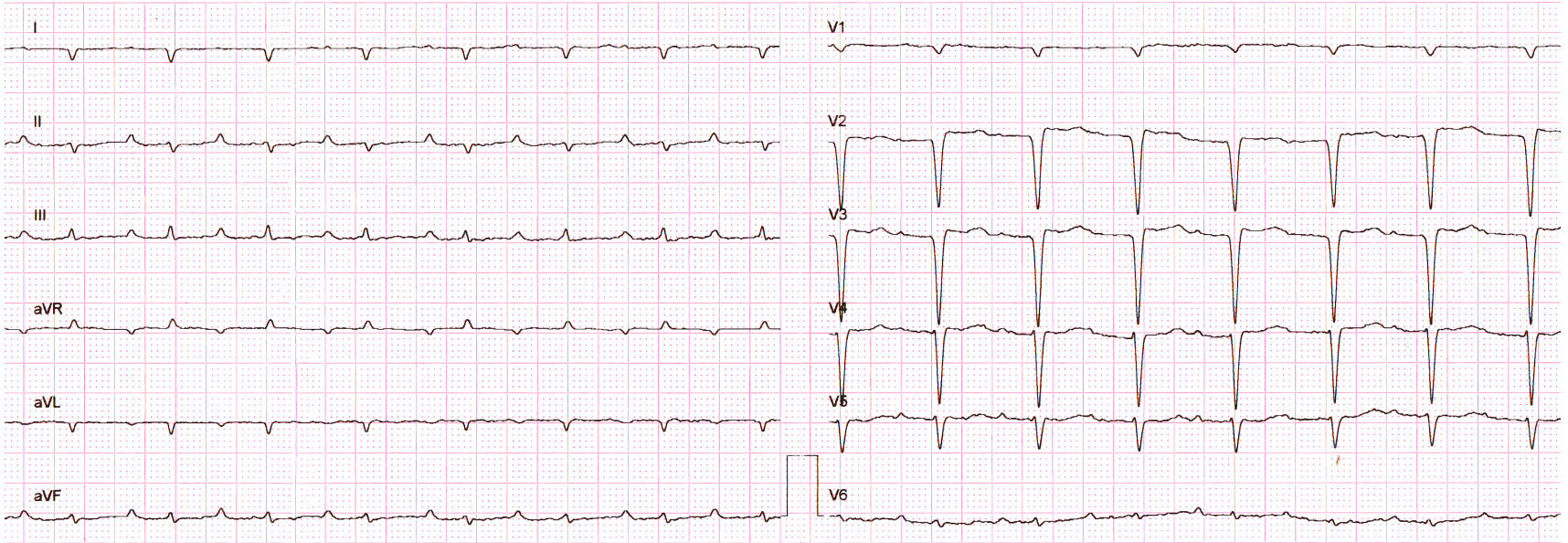

1. ábra

| Szívelégtelenség miatt felvett nőbeteg 12-elvezetéses EKG-ja

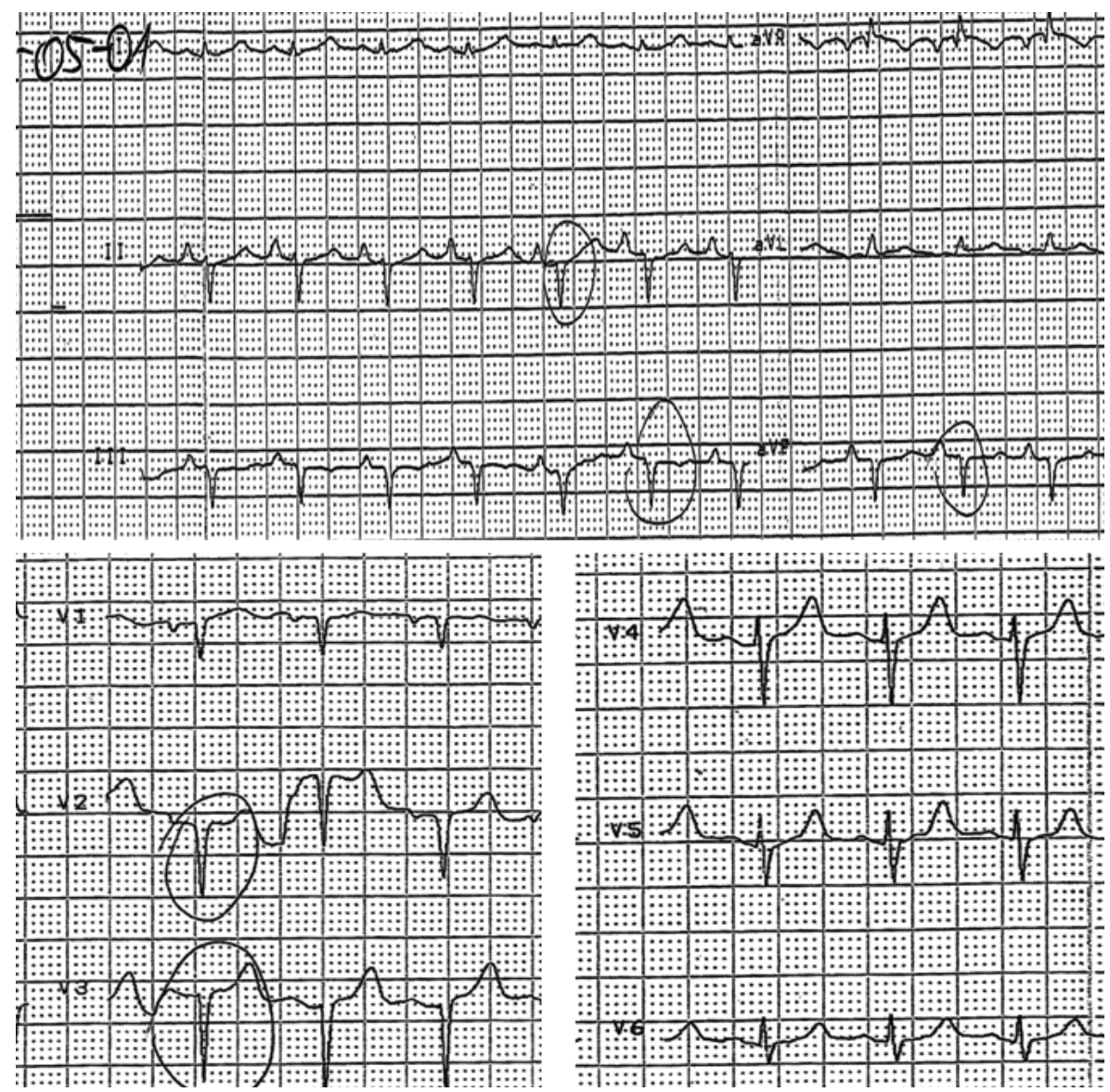

2. ábra | Két évvel korábban készült, preoperatív EKG az akkor még panaszmentes nőbetegnél

tó. A sinus-P-hullámok fix 260 msecundumos megnyúlt PQ-idővel vezetnek le a kamrára. A mellkasi elvezetésekben a QRS-eknek alacsony a kilengésük. A Sokolow-index alacsony, 0,5 mV. A Vl-3-elvezetésekben QS látható, az átmeneti zóna V6-ban van.

A később megszerzett második EKG-n (2. ábra) még nincsen PQ-megnyúlás, de az alacsony kilengések már megjelentek az inferior elvezetésekben, és a Vl- 3-elvezetésekben láthatók a pseudoinfarctusos Q-hullámok, amelyeket valaki be is karikázott, de aztán ennek további következménye nem lett. A Sokolow-index már itt is $1,5 \mathrm{mV}$ alatti, $0,9 \mathrm{mV}$. A II-III-as elvezetésekben látható QS-t bal anterior hemiblokknak is lehetne nézni, de akkor az aVL-elvezetésben qR-nek kellene lennie, és a II-es elvezetésben is kellene egy kis r-hullám. Így ezek a pseudoinfarctusos Q-hullámok semmikép- 
pen nem tekinthetők normálvariánsnak, amely felett el lehet siklani.

A pseudoinfarctusos Q-hullámok leggyakoribb okai a következők:

- pozicionális,

- WPW,

- bal kamrai hypertrophia (Vl-3-elvezetésekben),

- DCM,

- PTX (QS Vl-3),

- HCM (I, V5-6-elvezetésekben),

- emphysema (QS V3-4-elvezetésekben).

\section{Következtetés}

A szívelégtelenséget is okozó amyloidosis prognózisa igen rossz, a betegek fele meghal a diagnózist követő fél éven belül $[1,2]$. A szív- és csontvelö-transzplantációig eljutó betegek hazánkban raritásnak számítanak. Éppen ezért nagyon fontos a korai diagnózis. Az EKG-n látható pseudoinfarctusos Q-hullámok és a standard elvezetésekben jelentkező alacsony kilengések $(<0,5 \mathrm{mV})$ együttes fennállása esetén az amyloidosis specificitása, valamint pozitív prediktivitása 95\% feletti [3]. A low voltage irodalmi adatok alapján csak későn jelenik meg, és nem különíti el egymástól a különböző amyloidosisos formákat [4]. Az alacsony, 1,5 mV alatti Sokolow-index a leggyakoribb és a legkorábban megjelenő EKG-jel [4]. Esetünkben már 2 évvel korábban megvolt a szívamyloidosis minden EKG-jele. Végezetül szeretném felhívni a figyelmet arra, hogy a mindenki számára elérhető hasi subcutan zsírszövetből vett biopszia is segít felismerni a szisztémás amyloidosis diagnózisát [5].
Anyagi támogatás: A közlemény megírásával kapcsolatban a szerző anyagi támogatásban nem részesült.

A szerző a cikk végleges változatát elolvasta és jóváhagyta.

Érdekeltség: A szerzőnek nincsenek a cikk megírásával, illetve tartalmával kapcsolatban érdekeltségei.

\section{Irodalom}

[1] Pozsonyi Z, Vágó H, Tóth A, et al. Diagnosis and treatment of cardiac amyloidosis: Our experiences and review of the literature. [Szívamyloidosis diagnosztikája és kezelése. Tapasztalataink és irodalmi áttekintés.] Card Hung. 2016; 46: 292-300. [Hungarian]

[2] Jávorniczky NR, Bodó I, Masszi T, et al. Prognostic factors in light chain amyloidosis. [Prognosztikai tényezők könnyúláncamyloidosisban.] Orv Hetil. 2015; 156: 1577-1584. [Hungarian]

[3] Mussinelli R, Salinaro F, Alogna A, et al. Diagnostic and prognostic value of low $Q R S$ voltages in cardiac AL amyloidosis. Ann Noninvasive Electrocardiol. 2013; 18: 271-280.

[4] Cyrille NB, Goldsmith J, Alvarez J, et al. Prevalence and prognostic significance of low QRS voltage among the three main types of cardiac amyloidosis. Am J Cardiol. 2014; 114: 10891093.

[5] van Gameren II, Hazenberg BP, Bijzet J, et al. Diagnostic accu racy of subcutaneous abdominal fat tissue aspiration for detecting systemic amyloidosis and its utility in clinical practice. Arthritis Rheum. 2005; 54: 2015-2021.

(Tomcsányi János dr., Budapest, Árpád fejedelem útja 7., 1023 e-mail: tomcsanyij@gmail.com)

\section{MEGHÍVó}

\section{A Szent Margit Kórház Intézeti Tudományos és Kutatás Etikai Bizottsága tisztelettel meghívja az érdeklődőket a következő tudományos ülésére, amelyet a Lézerterápiai Szakrendelö rendez.}

Időpont: 2018. február 22. (csütörtök) 14:30

A rendezvény helyszíne: Szent Margit Kórház - Budapest III., Bécsi út 132. „A" épület, I. emelet, Konferenciaterem

Üléselnök: Prof. Dr. Berényi Marianne

\section{Előadások}

Dr. Fábián Sándor: „A lézerterápia 25 éves története a budapesti Szent Margit Kórházban 1992-2017.”

$$
\text { Minden érdeklődőt szeretettel várunk! }
$$

